\title{
Enterotoxigenecity and Typing of Clostridium perfringens Isolated from Raw Meat, Meat Products and Water Samples in Kashmir, India
}

\author{
Syed Akram Hussain*, M.M. Willayat and Mudasir A. Rather
} Division of Veterinary Public Health, Faculty of Veterinary Sciences and Animal Husbandry,
SKUAST-K, Shuhama, Alusteng, Srinagar-190006, J\&K, India

*Corresponding author

\section{Key w ords \\ C. perfringens type A, Enterotoxignecity, PCR cpe gene, Meat \& meat products}

Article Info

Accepted:

06 July 2018

Available Online:

10 August 2018

\section{A B S T R A C T}

The objective of the study was to see the prevalence of $C$. perfringens as well as to detect the enterotoxigenic genes in $C$. perfringens strains isolated from different meat and water samples in Kashmir, India. For this 275 different meat and meat product, and water samples were analyzed by standard bacteriological technique. All the Fifty nine (59) isolates recovered from these samples were typed according to their gene by multiplex PCR assay. Out of these, $44(74.57 \%)$ isolates were confirmed as $C$. perfringens type A based on the presence of alpha toxin gene ( were recovered from raw mutton (08) followed by mutton kabab (07) and mutton curry (06). Eight isolates (18.60\%) were classified as un-typable strains as no other gene was detected by PCR. To ascertain the prevalence of $C$. perfringens enterotoxin gene (cpe), all type A isolates were also screened for presence of cpe gene separately. From the PCR assay, it was found that $13(29.55 \%)$ of $C$. perfringens type A isolates carried the cpe gene of $233 \mathrm{bp}$. Isolates recovered from chicken pickle showed highest occurrence $(100 \%)$ of cpe gene followed by raw chicken $(50 \%)$ and mutton kabab (42.86\%). Strain having the cpe gene is of public health concern that is mainly responsible for causing food poisoning.

\section{Introduction}

Clostridium perfringens is one of the most widespread pathogenic bacteria in the environment (Aberle et al., 2001). The organism is responsible for several important enteric diseases, quite apart from its leading role as the cause of numerous different histotoxic infections both in humans and animals (Rood and Cole, 1991; Smedley and Mc Clane, 2004). Food-borne illness is caused by Clostridium perfringens throughout the world resulting from the consumption of contaminated food (Lin and Labbe, 2003). The organism is ubiquitously found in natural environment including soil, water source as well as in the intestinal tract of humans and animals and gains easy access to different foods and spices (McClane, 2001; Hörman et al., 2004; Aguilera et al., 2005). Several studies reported that meat and meat products, including poultry meat are the most common food vehicles of 'Clostridial' food poisoning (Hatakka and Halonen, 2000; McClane, 2001). The common occurrence of this organism in raw meat and retail food may be due to the 
contamination of the carcasses and meat with the intestinal contents of the animals during the slaughtering and evisceration process (Lin and Labbe, 2003; Wen and McClane, 2004). However, much less is known about the reservoirs for cpe-positive $C$. perfringens type A strains (Heikinheimo and Korkeala, 2005).

In Kashmir several meat products like mutton kabab, mutton rista, yakhni, chicken kabab etc. known as 'Kashmiri Wazwan' are very popular because of their delicious preparations. However, information regarding the microbiological quality of these products especially in relation to $C$. perfringens type A is very scanty in this region. So, the investigation was carried out to see the prevalence of $C$. perfringens type $\mathrm{A}$ in different animal products and to find out the sources of contamination of these foods, so that preventive measures can be taken.

\section{Materials and Methods}

\section{Isolation and identification of Clostridium species}

A total of two hundred seventy five $\left(n_{=} 275\right)$ samples comprising raw meat, meat products like mutton kabab, chicken kabab, mutton curry, chicken curry, mutton pickle and mutton rista (traditional Kashmiri dish), and water samples used for washing of carcasses were collected randomly from butcher shops, grocery stores and restaurants in different areas of Srinagar city in India. The samples were collected in sterile plastic zip lock sachet, brought to the laboratory on ice and processed immediately as per standard microbiological methods described by Food and Drug Administration (1998) and Holt et al., (1994). Briefly, $25 \mathrm{~g}$ of samples were blended in sterile blender with $225 \mathrm{ml}$ peptone water and then $1.0 \mathrm{ml}$ solution is plated in sterile egg-yolk free tryptose-sulfitecycloserine (TSC) agar (Hi-Media) and incubated at $37^{\circ} \mathrm{C}$ for $24 \mathrm{hrs}$ under anaerobic conditions using McIntosh jar with Anaerogas packs (Hi-media). Colonies from egg yolk free TSC agar plates were then inoculated into Fluid Thioglycollate (FTG) medium (HiMedia) and incubated for $24 \mathrm{~h}$ at $37^{\circ} \mathrm{C}$. A loopful of each thioglycollate culture medium was streaked on TSC agar containing egg yolk (Hi-media) and the plates were incubated in anaerobic jar for $24 \mathrm{~h}$ at $37^{\circ} \mathrm{C}$. Colonies with gray opaque zones caused by lecithinase activity were considered positive for $C$. perfringens. The isolates were further confirmed by Gram's staining, nitrate reduction, gelatin liquefaction, motility in motility-nitrate medium and fermentation of glucose and lactose. All confirmed isolates of $C$. perfringens were maintained in Cooked meat medium (CMM) (Hi-Media) for further studies.

\section{Characterization of $C$. perfringens}

Isolates of $C$. perfringens were screened for presence or absence of alpha toxin gene (cpa), beta toxin gene $(c p b)$, epsilon toxin gene (etx) and iota toxin gene $(i A)$ by multiplex PCR using specific primers (Table 1) as per the method of Songer and Meer (1996) and typing was done accordingly.

\section{Preparation of DNA template}

The template DNA was prepared by boiling and snap chill method. Cultures maintained in CMM were inoculated in $6 \mathrm{ml}$ FTG medium and incubated at $37^{\circ} \mathrm{C}$ for $18 \mathrm{hr}$. One (1.0) ml of broth culture was centrifuged by centrifugation at $5000 \mathrm{rpm}$ for 3 minutes. Cells were collected in micro-centrifuge tubes, pellet was washed once with $500 \mu \mathrm{l}$ sterile double distilled water and re-suspended in 100 $\mu 1$ sterile double distilled water. The microcentrifuge tubes were kept in boiling water bath for $10 \mathrm{~min}$ and then in crushed ice for 20 min. The chilled samples were centrifuged at 
$6000 \mathrm{rpm}$ for $5 \mathrm{~min}$ and the supernatant was collected which served as template. The DNA extracted from isolates was stored at $-20^{\circ} \mathrm{C}$ till further use.

\section{Detection of toxigenic genes}

The multiplex PCR was performed in a final reaction volume of $50 \mu \mathrm{l}$ containing $10 \mu \mathrm{l}$ of template DNA, $5 \mu 1$ of $1 \mathrm{X}$ PCR buffer (10 $\mathrm{mM}$ Tris- $\mathrm{HCl} \mathrm{pH} 8.3$ and $50 \mathrm{mM} \mathrm{KCl}$ ), 1.5 $\mathrm{mM} \mathrm{MgCl} 23 \mu \mathrm{l}, 0.4 \mathrm{mM}$ of each dNTPs $0.4 \mu \mathrm{l}$, $0.5 \mu \mathrm{l}$ of $0.2 \mu \mathrm{M}$ Taq DNA Polymerase (MBIFermentas, Mumbai, India) and $1 \mu 1$ of $0.2 \mu \mathrm{M}$ of each primer. Amplification reactions were carried out in a thermocycler (GeneAmp PCR System 9700, Applied Biosystems, Singapore) with initial denaturation at $94^{\circ} \mathrm{C}$ for $4 \mathrm{~min}$ followed by annealing of 30 cycles at $55^{\circ} \mathrm{C}$ for $2 \mathrm{~min}$, extension at $72^{\circ} \mathrm{C}$ for $3 \mathrm{~min}$ and a final extension of $72^{\circ} \mathrm{C}$ for $4 \mathrm{~min}$. The amplicons were separated on agarose gel $(2.0 \%)$ stained with ethidium bromide $(0.5 \mu \mathrm{g} / \mathrm{ml})$, applying 5-6 Volts $\mathrm{cm} \_1$, and sizes were estimated using 100 bp DNA ladder (MBI-Fermentas).

\section{Detection of enterotoxin gene (cpe)}

Detection of $C$. perfringens enterotoxigenic gene (cpe) was carried in all type A strain by PCR with specific primers as per the method of Songer and Meer (1996) as mentioned above and the specific forward and reverse primer pairs for cpe gene of $233 \mathrm{bp}$ were $5^{\prime}$ GGAGATGGTTGGATATTAGG-3 ${ }^{\prime}$ and $5^{\prime}$ GGACCAGCAGTTGTAGATA-3' (Czeczulin et al., 1993).

\section{Results and Discussion}

In the study, a total fifty nine (59) Clostridium perfringens isolates were recovered, of which 43 isolates from meat products and 16 from water used for washing carcasses (Table 2 and 3). The isolates were identified as $C$. perfringens on the basis of common morphological, cultural and biochemical characteristics along with ATCC -13124 strains (Table 4).

All these isolates were typed on the basis of presence or absence of toxigenic genes ( $c p a$, $c p b$, etx and $i A)$ detected by multiplex PCR. Out of 43 isolates recovered from meat and meat products, $35(81.40 \%)$ were confirmed as type A which possesses alpha toxin gene (cpa) of $324 \mathrm{bp}$ size of DNA (Plate 6). None of the isolates contain any of $c p b, e t x$ and $i A$ genes as the product failed to amplify for these genes. Highest (08) number of type A isolates were found in raw mutton followed by mutton kabab (07) and mutton curry (06). Eight isolates $(18.60 \%)$ were classified as un-typed strain as the strain unable to amplify any of the genes in PCR. Out of 16 isolates recovered from water, $09(56.25 \%)$ were typed as type A. In an investigation, Elham and Nahla (2011) found that among toxigenic types, type A was the most predominant type of $C$. perfringens (46.8\%) compared to type D $(19.5 \%)$ and mixed types $(23.3 \%)$ in the Egyptian meat products. PCR has been widely used in identifying the representative toxin genes of $C$. perfringens because of its high sensitivity (Songer and Meer, 1996). Many surveys on the incidence of $C$. perfringens in raw and processed foods have been conducted without regard of whether the isolates were enterotoxigenic or not (Eman et al., 2007). In the current study, to ascertain the prevalence of cpe positive strains, all type $\mathrm{A}$ isolates were again examined for cpe genes by PCR. From the PCR assay, it was found that 11 (31.43\%) type A isolates from meat and meat products found having cpe gene of approximately 233 bp product size (Plate 7). Highest number of cpe positive strains (03 of 07) was found in mutton kabab (Table 2). Two isolates $(22.22 \%)$ recovered from water were also confirmed as cpe positive strains by PCR (Table 3). 
Table.1 Specific primers used for the detection of $C$. perfringens toxin genes

\begin{tabular}{|c|c|c|c|}
\hline $\begin{array}{l}\text { Target } \\
\text { genes }\end{array}$ & Primer sequences $\left(5^{\prime}-3^{\prime}\right)$ & $\begin{array}{l}\text { Amplicon } \\
\text { size (bp) }\end{array}$ & Reference \\
\hline Cpa & $\begin{array}{l}\text { For 5'-GCTAATGTTACTGCCGTTGA-3' } \\
\text { Rev 5'-CCTCTGATACATCGTGTAAG-3' }\end{array}$ & 324 & $\begin{array}{l}\text { Titball et al., } \\
\text { (1989) }\end{array}$ \\
\hline$C p b$ & $\begin{array}{l}\text { For 5'-GCGAATATGCTGAATCATCTA- } 3^{\prime} \\
\text { Rev5' } 5^{\prime} \text {-GCAGGAACATTAGTATATCTTC- } 3^{\prime}\end{array}$ & 180 & $\begin{array}{l}\text { Hunter et al., } \\
\text { (1993) }\end{array}$ \\
\hline Etx & $\begin{array}{l}\text { For 5'-GCGGTGATATCCATCTATTC-3' } \\
\text { Rev 5'-CCACTTACTTGTCCTACTAAC- } 3^{\prime}\end{array}$ & 655 & $\begin{array}{l}\text { Hunter et al., } \\
\text { (1992) }\end{array}$ \\
\hline Ia & $\begin{array}{l}\text { For 5'-ACTACTCTCAGACAAGACAG-3' } \\
\text { Rev 5'-CTTTCCTTCTATTACTATACG-3 } 3^{\prime}\end{array}$ & 446 & $\begin{array}{l}\text { Perelle et al., } \\
\text { (1993) }\end{array}$ \\
\hline
\end{tabular}

For: Forward, Rev: Reverse

Table.2 Typing of $C$. perfringens isolates by PCR recovered from meat and meat products

\begin{tabular}{|c|c|c|c|c|c|}
\hline \multirow{2}{*}{$\begin{array}{l}\text { Type of } \\
\text { Samples }\end{array}$} & \multirow{2}{*}{$\begin{array}{l}\text { No. of } \\
\text { C. perfringens } \\
\text { isolates }\end{array}$} & \multicolumn{4}{|c|}{ C.perfringens types } \\
\hline & & $\begin{array}{c}\text { Type A } \\
(\%)^{*}\end{array}$ & $\begin{array}{c}\text { Untypable } \\
(\%)^{*}\end{array}$ & $\begin{array}{c}\text { cpe positive } \\
\text { type A } \\
(\%)^{* *}\end{array}$ & $\begin{array}{c}\text { cpe negative } \\
\text { type A } \\
(\%)^{* *}\end{array}$ \\
\hline Raw Mutton & 8 & $\begin{array}{c}8 \\
(100.0)\end{array}$ & 0 & $\begin{array}{c}2 \\
(25.0)\end{array}$ & $\begin{array}{c}6 \\
(75.0)\end{array}$ \\
\hline Raw Chicken & 6 & $\begin{array}{c}4 \\
(66.67)\end{array}$ & $\begin{array}{c}2 \\
(33.33)\end{array}$ & $\begin{array}{c}2 \\
(50.0)\end{array}$ & $\begin{array}{c}2 \\
(50.0)\end{array}$ \\
\hline Mutton kabab & 9 & $\begin{array}{c}7 \\
(77.78)\end{array}$ & $\begin{array}{c}2 \\
(22.22)\end{array}$ & $\begin{array}{c}3 \\
(42.86)\end{array}$ & $\begin{array}{c}4 \\
(57.14)\end{array}$ \\
\hline Chicken kabab & 5 & $\begin{array}{c}3 \\
(60.0)\end{array}$ & $\begin{array}{c}2 \\
(40.0)\end{array}$ & $\begin{array}{c}1 \\
(33.33)\end{array}$ & $\begin{array}{c}2 \\
(66.67)\end{array}$ \\
\hline Mutton curry & 7 & $\begin{array}{c}6 \\
(85.71)\end{array}$ & $\begin{array}{c}1 \\
(14.29)\end{array}$ & $\begin{array}{c}1 \\
(16.67)\end{array}$ & $\begin{array}{c}5 \\
(83.33)\end{array}$ \\
\hline Chicken curry & 2 & $\begin{array}{c}2 \\
(100.0)\end{array}$ & 0 & 0 & $\begin{array}{c}2 \\
(100.0)\end{array}$ \\
\hline Mutton pickle & 4 & $\begin{array}{c}4 \\
(100.0)\end{array}$ & 0 & $\begin{array}{c}1 \\
(25.0)\end{array}$ & $\begin{array}{c}3 \\
(75.0)\end{array}$ \\
\hline Mutton rista & 2 & $\begin{array}{c}1 \\
(50.0)\end{array}$ & $\begin{array}{c}1 \\
(50.0)\end{array}$ & $\begin{array}{c}1 \\
(100.0)\end{array}$ & 0 \\
\hline Total & 43 & $\begin{array}{c}35 \\
(81.40)\end{array}$ & $\begin{array}{c}8 \\
(18.60)\end{array}$ & $\begin{array}{c}11 \\
(31.43)\end{array}$ & $\begin{array}{c}24 \\
(68.57)\end{array}$ \\
\hline
\end{tabular}


Table.3 Typing of $C$. pefringens isolates by PCR recovered from water

\begin{tabular}{|c|c|c|c|c|c|}
\hline \multirow{2}{*}{$\begin{array}{l}\text { Type of } \\
\text { Samples }\end{array}$} & \multirow{2}{*}{$\begin{array}{l}\text { No. of } C \text {. } \\
\text { perfringens } \\
\text { isolates }\end{array}$} & \multicolumn{4}{|c|}{ C.perfringens types } \\
\hline & & $\begin{array}{c}\text { Type A } \\
(\%)^{*}\end{array}$ & $\begin{array}{c}\text { Untypable } \\
(\%)^{*}\end{array}$ & $\begin{array}{c}\text { cpe positive } \\
\text { type A } \\
(\%) * *\end{array}$ & $\begin{array}{c}\text { cpe negative } \\
\text { type A } \\
(\%) * *\end{array}$ \\
\hline $\begin{array}{l}\text { Lamb washing } \\
\text { water }\end{array}$ & 6 & $\begin{array}{c}5 \\
(83.33)\end{array}$ & $\begin{array}{c}1 \\
(16.67)\end{array}$ & $\begin{array}{c}1 \\
(20.0)\end{array}$ & $\begin{array}{c}4 \\
(80.0)\end{array}$ \\
\hline $\begin{array}{l}\text { poultry } \\
\text { washing water }\end{array}$ & 3 & $\begin{array}{c}2 \\
(66.67)\end{array}$ & $\begin{array}{c}1 \\
(33.33)\end{array}$ & 0 & $\begin{array}{c}2 \\
(100.0)\end{array}$ \\
\hline $\begin{array}{l}\text { Scalding tank } \\
\text { water }\end{array}$ & 7 & $\begin{array}{c}2 \\
(28.57)\end{array}$ & $\begin{array}{c}5 \\
(71.43)\end{array}$ & $\begin{array}{c}1 \\
(50.00)\end{array}$ & $\begin{array}{c}1 \\
(50.0)\end{array}$ \\
\hline Total & 16 & $\begin{array}{c}9 \\
(56.25)\end{array}$ & $\begin{array}{c}7 \\
(43.75)\end{array}$ & $\begin{array}{c}2 \\
(22.22)\end{array}$ & $\begin{array}{c}7 \\
(77.78)\end{array}$ \\
\hline
\end{tabular}

*\% Calculated according to the number of C.perfringens

** Calculated according to the number of C.perfringens type A

Table.4 Biochemical characteristics of $C$. perfringens isolates from meat, meat products and carcass washings

\begin{tabular}{|c|c|c|c|c|}
\hline No. & Name of the test & Characteristics & \begin{tabular}{|l} 
ATCC- \\
13124 \\
\end{tabular} & $\begin{array}{l}\text { Field } \\
\text { isolates }\end{array}$ \\
\hline 1 & $\begin{array}{l}\text { Growth on selective TSC agar } \\
\text { (without egg yolk) }\end{array}$ & $\begin{array}{l}\text { Demonstration of black } \\
\text { colonies (Plate 1) }\end{array}$ & ++ & ++ \\
\hline 2 & TSC (with egg yolk) & $\begin{array}{l}\text { Lecithino-vitaline reaction } \\
\text { (Plate 2) }\end{array}$ & + & + \\
\hline 3 & Gram staining & $\begin{array}{l}\text { Gram positive large rods } \\
\text { (Plate } 3 \text { ) }\end{array}$ & + & + \\
\hline 4 & $\begin{array}{l}\text { Motility test (motility nitrate } \\
\text { medium) }\end{array}$ & Motility & - & - \\
\hline 5 & Malachite green staining & Presence of spores & + & + \\
\hline 6 & Litmus milk test & $\begin{array}{l}\text { Stormy fermentation with } \\
\text { gas (Plate 4)) }\end{array}$ & + & + \\
\hline 7 & Blood agar (5\% sheep blood) & $\begin{array}{l}\beta \text {-haemolytic, double zone } \\
\text { of haemolysis (Plate } 5 \text { ) }\end{array}$ & + & + \\
\hline 8 & Nitrate reduction test & $\begin{array}{l}\text { Reduction of nitrates to } \\
\text { nitrites }\end{array}$ & + & + \\
\hline 9 & Gelatin liquefaction test & After 48 hours & + & + \\
\hline \multirow[t]{4}{*}{10} & Carbohydrate fermentation & & & \\
\hline & & Glucose & $\begin{array}{l}\text { Acid and } \\
\text { gas }\end{array}$ & ++ \\
\hline & & Lactose & $\begin{array}{l}\text { Acid and } \\
\text { gas }\end{array}$ & ++ \\
\hline & & Maltose & $\begin{array}{l}\text { Acid and } \\
\text { gas }\end{array}$ & ++ \\
\hline
\end{tabular}


Plate.1 Typical black colour colonies of $C$. perfringens on tryptose sulfite-cyclosterin (without egg yolk) agar

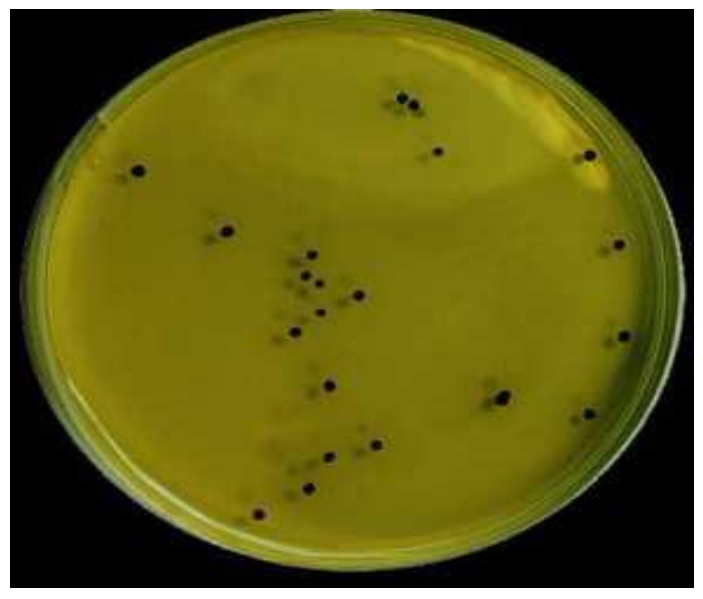

Plate.2 Colonies of $C$. perfringens on tryptose-sulfite-cycloserine (with egg yolk) agar showing lechithinase activity

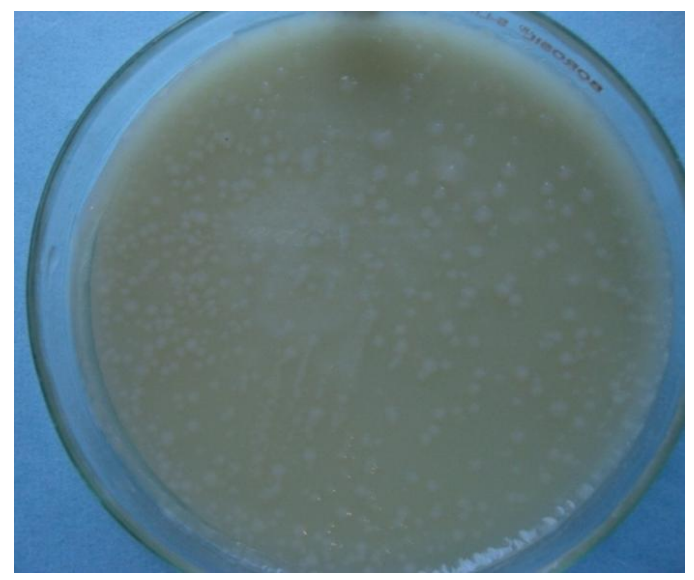

Plate.3 Gram positive large rods of $C$. perfringens (100x)

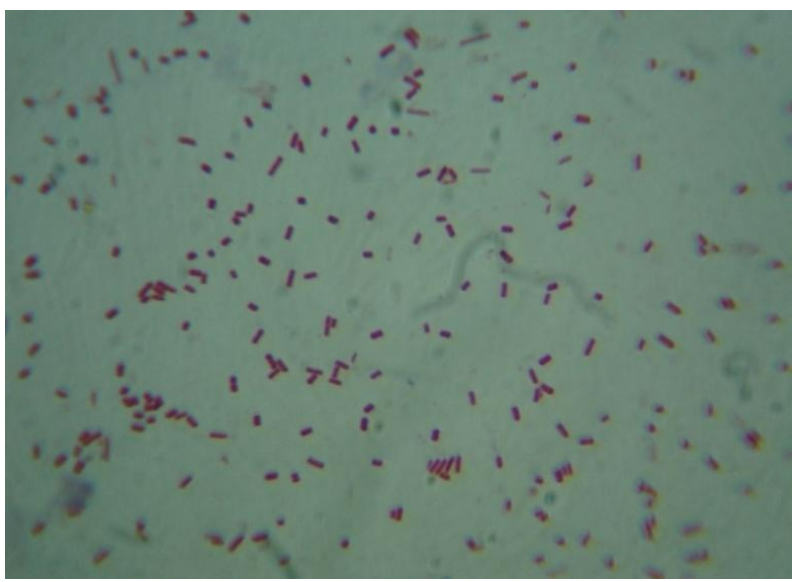


Plate.4 Stormy fermentation produced by $C$. perfringens in litmus milk

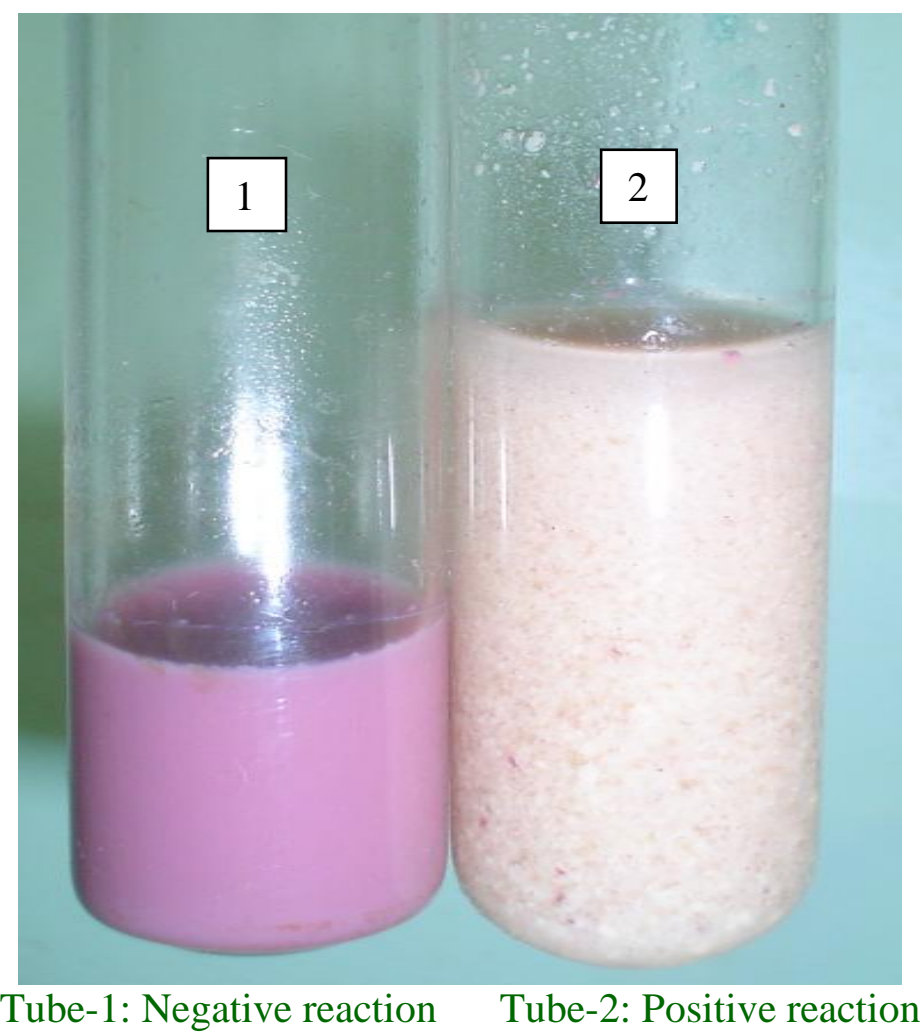

Plate.5 $\beta$ haemolysis produced by $C$. perfringens type A in 5\% sheep blood agar

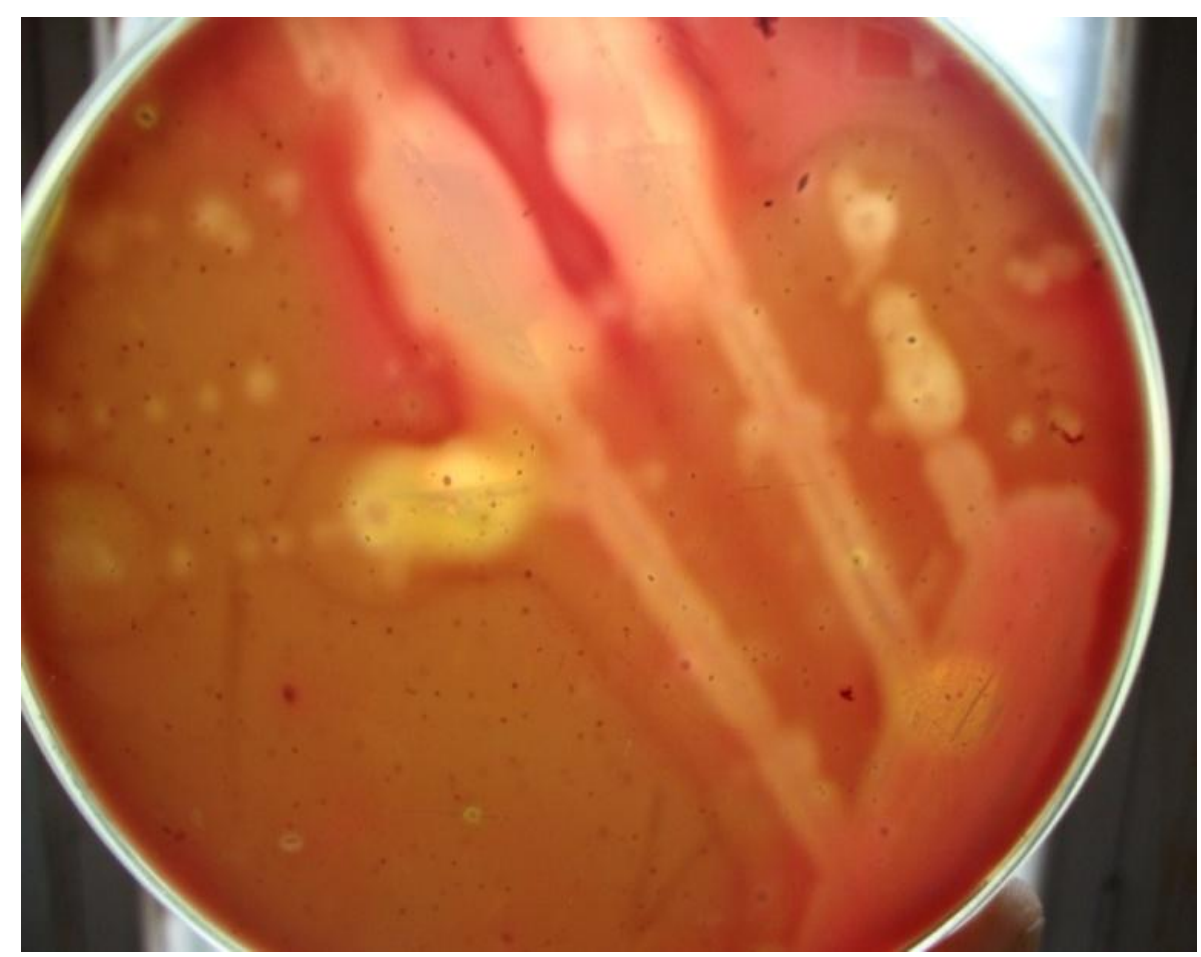


Plate.6 Bands revealing amplification of $C$. perfringens alpha toxin gene (cpa) by PCR

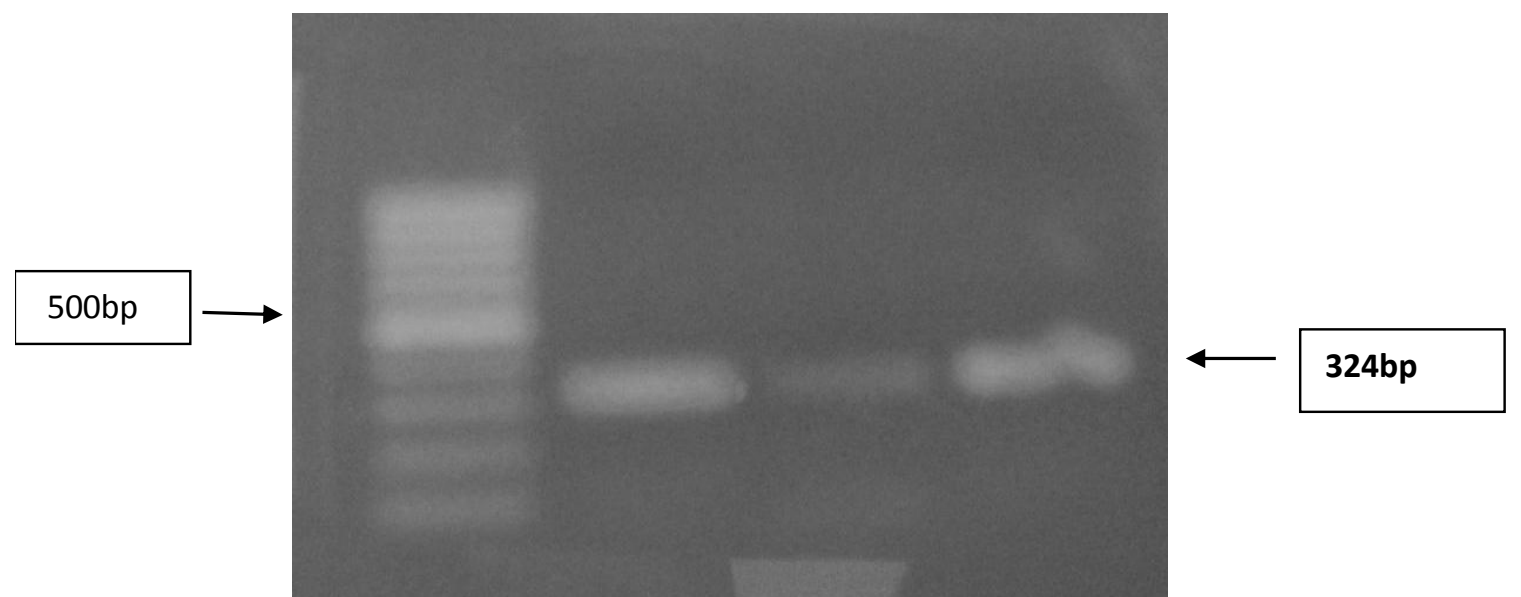

Lane 1: Standard molecular weight marker ladder (100 bp)

Lane 2, 3 and 4: Amplified C. perfringens alpha toxin gene (cpa) at $324 \mathrm{bp}$

Plate.7 Bands revealing amplification of C. perfringens entero-toxin gene (cpe) by PCR

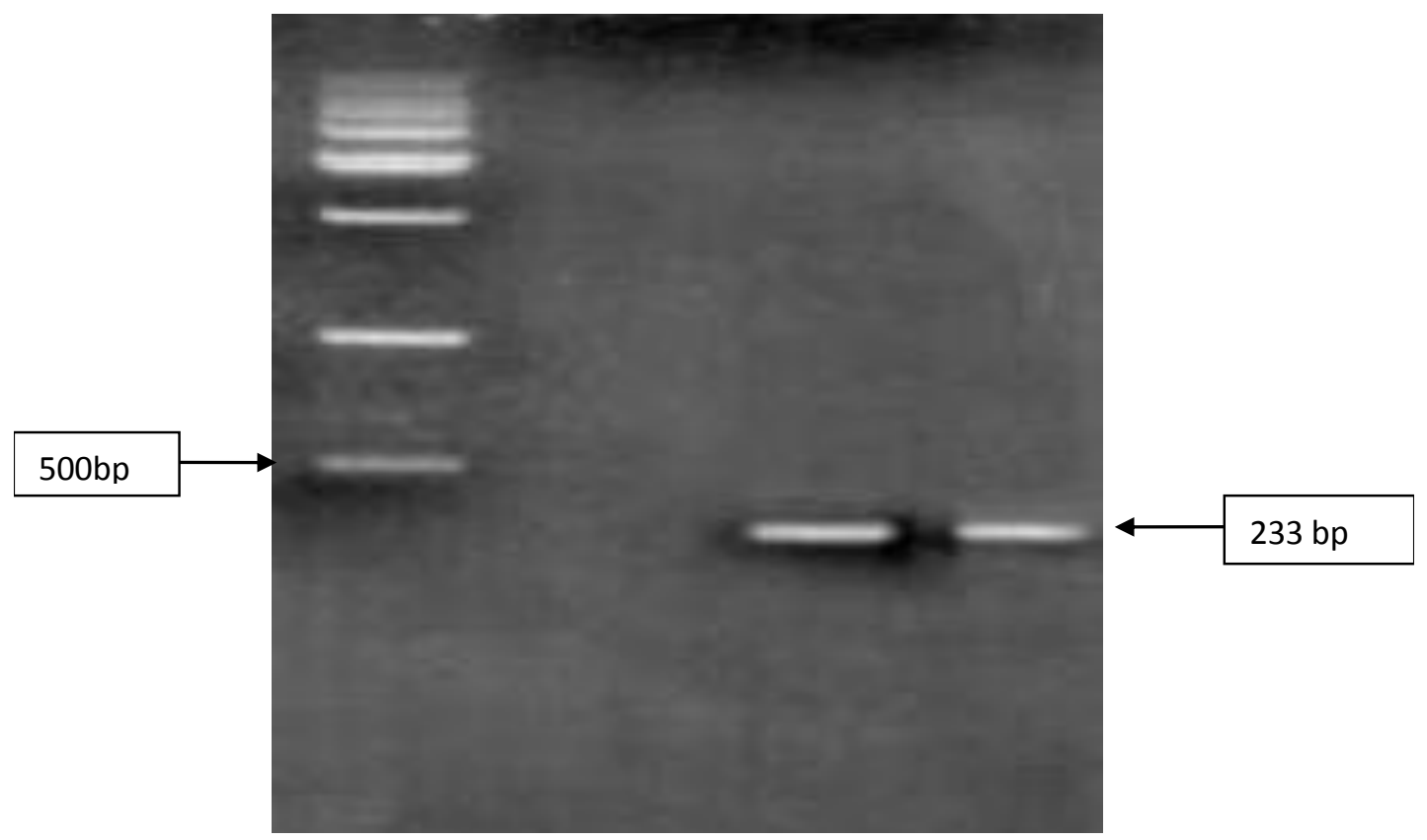

Lane 1: Standard molecular weight marker ladder (100 bp)

Lane 2: Negative sample

Lane 3 and 4: Amplified C. perfringens entero-toxin gene (cpe) at $233 \mathrm{bp}$

Earlier many investigators reported the presence of enterotoxin gene in Clostridium perfringens type $\mathrm{A}$ isolates, where both alpha and enterotoxin gene were detected by PCR (Czeczulin et al., 2005; Eman et al., 2007; Singh et al., 2005). Singh et al., (2005) reported that 9.3, 32.4 and $15.5 \%$ isolates of
C. perfringens from buffalo, goat and poultry meat respectively possessed the entero-toxin gene (сpe). However, Lin and Labbe (2003) could not detect any cpe genes in 133 food samples and concluded the rarity of cpe positive strains in retail foods and the genetic diversity among non-outbreak strains in 
United States of America. Recovery of higher percentage $(31.43 \%)$ of cpe positive $C$. perfringens type $\mathrm{A}$ isolates from meat and meat products than global average $(5 \%)$ is of serious concern in respect of public health. Daube et al., (1996) and Songer and Meer (1996) have indicated that less than $5 \%$ of the global $C$. perfringens population recovered from various sources only carries the enterotoxin gene (cpe).

In the study $C$. perfringens was found as a common contaminant of meat and meat products. Excessively contaminated meat and meat products with this microorganism are undesirable from public health point of view. Prevalence of toxigenic genes (cpe) in some type A isolates is epidemiologically significant which explain the association of the bacterium in food poisoning cases in this region. Recovery of higher percentage (31.43\%) of cpe positive C. perfringens type A isolates in the study than global average $(5 \%)$ is of a serious concern with respect to public health. As typing procedure like toxin neutralization test and animal inoculation test consumes a lot of anti-sera requiring experimental animal, PCR can be used to determine the presence of toxin genes and for typing of $C$. perfringens accordingly. This technique also gives the opportunity to type the isolates that could not be typed by toxin neutralization test.

\section{References}

Aberle, E. D., Forrest, J. C., Gerrard, D. E. and Mills, E. W. (2001). Principles of Meat Science. $4^{\text {th }}$ ed. Kendall / Hunt Publ. Co., Dubuque, IA.

Aguilera, M.O., Stagnitta, P.V., Micalizzi, B., and de Guzman, A.M. (2005). Prevalence and characterization of Clostridium perfringens from spices in Argentina. Anaerobe 11: 327-334.
Czeczulin, J.R., Hanna, P.C., and Mcclane, B.A. (1993). Cloning, nucleotide sequencing, and expression of the Clostridium perfringens enterotoxin gene in Escherichia coli. Infection and Immunity 61: 3429-3439.

Daube, G., Simon, P., Limbourg, B., Manteca, C., Mainil, J. and Kaeckenbeeck, A. (1996). Hybridization of 2,659 Clostridium perfringens isolates with gene probes for seven toxins $(\alpha, \beta, \varepsilon, 1, \theta, \mu$ and enterotoxin) and for sialidase. American Journal of Veterinary Research 57:496501.

Elham I.A. and Nahla A. A. (2011). Incidence of Clostridium perfringens in Meat Products at Some Egyptian Governorates, International Journal of Microbiological 2 (3): 196-203.

Eman, M. Nasr, Amal, A. Shehta and Hala, A. Amer. (2007). Enterotoxigenicity and Typing of Clostridium perfringens Isolates from Some Poultry Products in Egypt. Journal of Applied Sciences Research 3(12): 1804-1808.

Food and Drug Administration. (1998). Bacteriological analytical manual, 8th ed. Association of Official Analytical Chemists International, Gaithersburg, Md.

Hatakka, M. and Halonen, H. (2000). FoodBorne and Waterborne Outbreaks in Finland in 1999. National Food Administration research notes, Vol. 7. Helsinki, Finland: National Food Administration.

Heikinheimo and Korkeala. (2005). Multiplex PCR assay for toxinotyping Clostridium perfringens isolates obtained from Finnish broiler chickens. Letters in Applied Microbiology 40: 407-411

Holt, J.G., Krige, N.R., Sneeth, P.H.A., Staley, J.T. and Williams, S.T. (1994). Bergey's Manual of Determinative 
Bacteriology. $9^{\text {th }}$ edn. Williams and Wilkins, Baltimore, USA, pp: 749-755.

Hörman, A., Rimhanen-Finne, R., Maunula, L., von Bonsdorff, C.H., Torvela, N., Heikinheimo, A., and Hänninen, M-L. (2004). Campylobacter spp., Giardia spp., Cryptosporidium noroviruses and indicator organisms in surface water in southwestern Finland, 2000-2001. Applied and Environmental Microbiology 70: 87-95.

Lin Y.T. and Labbe, R. (2003). Enterotoxigenicity and Genetic Relatedness of Clostridium perfringens Isolates from Retail Foods in the United States. Applied and Environmental Microbiology 69:1642-1646.

McClane, B.A. (2001). Clostridium perfringens. 351-372. In: Food microbiology: fundamentals and frontiers, 2nd ed. ASM Press, Washington DC, USA.

Rood, J. I. and Cole, S.T. (1991). Molecular genetics and pathogenesis of Clostridium perfringens. Neuobiology Review. 55: 621-48.

Singh, R., Bhilegaonkar, K. N. and Agarwal, R. K. (2005). Studies on occurrence and characterization of Clostridium perfringens from select meats. Journal of Food Safety 25: 146-156.

Smedley, J.G., and McClane, B.A. (2004). Fine mapping of the N-terminal cytotoxicity region of Clostridium perfringens enterotoxin by site-directed mutagenesis. Infection and Immunity 72: 6914-6923.

Songer, J.G., Meer, R.R. (1996). Genotyping of Clostridium perfringens by polymerase chain reaction is a useful adjunct to diagnosis of clostridial enteric disease in animals. Anaerobe 2(4): 197-203.

Titball, R.W., Hunter, S.E.C., Martin, K.L., Morris, A.D., Shuttleworth, A.D., Rubdige, T., Anderson, D.W. and Kelly, D.C. (1989). Molecular cloning and nucleotide sequence of the alpha-toxin (phospholipase C) of Clostridium perfringens. Infection and Immunity 57(2), 367-376.

Wen, Q. and McClane, B. A. (2004). Detection of enterotoxigenic Clostridium perfringens type A isolates in American retail foods. Applied Environmental Microbiology 70:26852691.

\section{How to cite this article:}

Syed Akram Hussain, M.M. Willayat and Mudasir A. Rather. 2018. Enterotoxigenecity and Typing of Clostridium perfringens Isolated from Raw Meat, Meat Products and Water Samples in Kashmir, India. Int.J.Curr.Microbiol.App.Sci. 7(08): 480-489.

doi: https://doi.org/10.20546/ijcmas.2018.708.053 